\title{
LEGAL ADMISSION OF LEGAL SOCIETY CONDUCTING THE NATIONAL PARK OF KAYAN MENTARANG (TNKM)
}

\author{
Marthina, Afdhala, Yasser Arafata, Wiwin DRFa \\ a Departement of Private Law, Borneo University Tarakan, Indonesia \\ Email: Marthin.fhub@gmail.com/marthin@borneo.ac.id
}

\begin{abstract}
The Kayan Mentarang National Park (KNPM) area located in the Heart of Borneo (HoB) in North Kalimantan lives various Dayak sub-tribes. They inhabit and keep the forest so that the forest remains safe and sustainable. Indigenous and tribal peoples who have customary forest areas in which their status of appointment as KMNP initially may receive, so that the process can continue in the inaugural process. But with the development of information and circumstances the situation was changed and now the indigenous people reject the pegat which will be done

The legal issues that serve as the purpose of this paper are: the recognition of traditional rights of indigenous and tribal communities and the recognition of local wisdom in the management of Kayan Mentarang National Park. Using the normative juridical and customary law approaches that this method is expected to address the issue of law.

The dynamics of the development of society and law can change the legal status of both government and customary law community to a legal fact. Forests as natural resources and the environment are constitutionally the government's obligation to regulate them. Inauguration of customary forest as a national park brings legal consequences to rights and obligations. Implementation of laws and regulations is limited by Human Rights. It is necessary to harmonize the law, so that both the interests of indigenous and tribal peoples, as the inhabitants as well as the natural resources, the environment, and the biodiversity as the interests of mankind are not mutually harmful.
\end{abstract}

Keywords: Customary Law Community, Traditional Rights, National Park

\section{PENDAHULUAN}

Taman Nasional Kayan Mentarang selanjutnya disingkat TNKM merupakan hutan yang memilki kekayaan alam dan kekayaan fauna yang melimpah dengan luas 1.306.500 Hektar. TNKM awalnya merupakan cagar alam yang ditetapkan berdasarkan keputusan Menteri Pertanian No. 84/Kpts/Um/II/1980, Tanggal 25 November 1980, serta berdasarkan Undangundang No. 5 Tahun 1967 tentang pokok-pokok kehutanan, dengan dasar aturan tersebut maka TNKM menjadi wilayah hutan yang wajib dijaga kelestariannya. Penetapan sebagai TNKM didasarkan melalui Keputusan Menteri Kehutanan No. 631/Kpts-II/1996, tanggal 7 Oktober 1996 dan berdasarkan Undang-undang No. 5 Tahun 1990 tentang Konservasi Sumber Daya Alam Hayati dan Ekosistemnya.

TNKM sebagai kawasan hutan juga digunakan masyarakat untuk bermukim dan mencari sumber kehidupan, tercatat berdasarkan data WWF terdapat 27.0000 (dua puluh tujuh ribu) 
warga suku dayak yang tersebar kedalam 11 wilayah adat besar yang tiap wilayah adat tersebut dipimpin oleh kepala adat atau ketua adat. Desa yang berada di wilayah TNKM dihuni masyarakat adat dan dipimpin oleh kepala adat, dimana masyarakat tersebut bergantung dari pemanfaatan sumber daya alam kawasan TNKM sejak turun temurun.

TNKM dikukuhkan sebagai kawasan hutan dengan tujuan untuk melestarikan keanekaragaman hayati dan ekosistem serta dapat mendukung peningkatan kesejahteraan dan mutu kehidupan manusia terkhusus bagi masyarakat hukum adat yang telah bermukim di wilayah tersebut. Pelestarian alam dilakukan dengan tidak bertentangan dengan kepentingan nasional.Menurut A.Suryaman Mustari Pide, anak kalimat "sekedar diperlukan, tidak bertentangan dengan kepentingan nasional, menurut ketentuan-ketentuan Peraturan Pemerintah" merupakan kriteria yang tidak tegas, tidak jelas, dan mensyaratkan adanya Peraturan Pemerintah yang belum ada sampai sekarang, tentang kapan hak menguasai dari Negara itu diperlukan untuk dikuasakan kepada daerah Swatantra (sekarang: daerah otonom) atau masyarakat hukum adat16. Berkenaan dengan hal ini menurut Muhammad Bakri semua kebijakan pemerintah di bidang agraria (tanah) yang dituangkan dalam bentuk peraturan perundang-undangan, harus dapat meningkatkan kemakmuran, kesejahteraan rakyat Indonesia seluruhnya ${ }^{17}$.

Pengelolaan bersama antara masyarakat hukum adat dan pemerintah terhadap kawasan TNKM dilakukan sejak World Wide Fund for Nature selanjutnya disingkat (WWF) dan Departemen Kehutanan melalui Direktorat Jenderal PHKA menandatangani Nota Kesepahaman (MoU) untuk Mendukung upaya konservasi di Indonesia. TNKM, WWF Indonesia memfasilitasi penyiapan Rencana Pengelolaan TNKM jangka waktu 25 tahun, membangun sistem pengelolaan kolaboratif dengan para pihak terkait, merintis inisiatif kerja sama konservasi lintas batas dengan Taman Nasional Pulong Tau (Sarawak, Malaysia), penelitian keanekaragaman hayati, pemetaan partisipatif, pemberdayaan masyarakat, pendidikan dan penyuluhan, monitoring keamanan kawasan dan memfasiliatasi terbentuknya inisiatif Heart of Borneo (HoB).18

Masyarakat hukum adat dalam wilayah TNKM adalah masyarakat yang hidup dengan cara komunal dan tradisional serta memiliki peran yang sangat penting dalam menjaga kelestarian lingkungan hidup. Perlindungan secara hukum diperlukan bagi masyarakat hukum adat agar dalam setiap kegiatannya yang berhubungan dengan memanfaatkan TNKM memiliki dasar legalitas yang jelas. Wewenang negara untuk mengatur hubungan hukum antara orang-orang

\footnotetext{
${ }^{16}$ A. Suriyaman Mustari Pide, Dilema Hak Kolektif Eksistensi Dan Realitas Sosialnya Pasca UUPA (makassar: Pelita Pustaka, 2007). Hlm. 6

${ }^{17}$ Muhammad Bakri, Hak Menguasai Tanah Oleh Negara (Paradigma Baru Untuk Reformasi Agraria) (Yogyakarta, 2007). Hlm. 6

${ }^{18} \mathrm{https} / / /$ www.wwf.or.id/program/wilayah_kerja_kami/kalimantan/kayanmentarang/pengelolaan_kola boratif.cfm
} 
termasuk masyarakat hukum adat dengan tanah terkait erat dengan hubungan hukum antara negara dengan tanah.Hal ini disebabkan, hubungan hukum antara negara dengan tanah sangat mempengaruhi dan menentukan isi peraturan perundang-undangan yang mengatur tentang hubungan hukum antara orang-orang dengan tanah dan masyarakat hukum adat dengan tanah ulayatnya serta pengakuan dan perlindungan hak-hak yang timbul dari hubungan-hubungan hukum tersebut ${ }^{19}$.

Undang-undang No. 41 Tahun 1999 Tentang Kehutanan menjadi dasar pemerintah menetapkan TNKM menjadi tanah negara dimana dalam penyelenggaraannya bertujuan untuk sebesar-besarnya kemakmuran rakyat yang berkeadilan dan berkelanjutan. Fakta yang terjadi selama sepuluh tahun Undang-Undang Kehutanan digunakan sebagai alat bagi pemerintah untuk mengambil alih hak kesatuan masyarakat hukum adat atas wilayah adatnya dan selanjutnya hutan tersebut diserahkan kepada pemilik modal melalui berbagai bentuk perizinan dengan tujuan eksploitasi tanpa memperhatikan hak masyarakat hukum adat dan kearifan lokal. Hal ini menimbulkan konflik dimana-mana dan berkepanjangan sehingga mengganggu pembangunan dan produksi yang selalu dikalahkan adalah masyarakat hukum adat.

Hukum yang mengatur pengakuan dan perlindungan tersebut sangat diperlukan untuk memberikan jaminan kepastian hukum kepada masyarakat agar hak-hak atas tanahnya tidak dilanggar oleh siapapun. Oleh karena itu sangat tidak tepat jika melihat hubungan negara dengan tanah terlepas dengan hubungan antara masyarakat hukum adat dengan tanah ulayatnya. Idealnya hubungan ketiga hak itu terjalin secara harmonis dan seimbang. Artinya, ketiga hak itu sama kedudukan dan kekuatannya, dan tidak saling merugikan.

Hak Ulayat yaitu hak masyarakat hukum adat terhadap tanah adat telah ada sebelum terbentuknya NKRI. Tanah adalah hak dasar setiap manusia yang berfungsi sebagai salah satu sumber daya yang menjadi kebutuhan dan kepentingan dalam pembangunan. Masyarakat hukum adat adalah manusia yang hidup di wilayah Indonesia dimana memiliki kesadaran akan arti fungsi nilai tanah dan Hak Asasi Manusia. Pasal 9 ayat (1) Undang-Undang No.39 Tahun 1999 tentang Hak Asasi Manusia menjelaskan bahwa tanah diperlukan dalam pemenuhan hak dan kesejahteraan dalam bentuk hak milik, yang dipunyai bagi diri sendiri maupun bersama-sama dengan orang lain untuk pengembangan dirinya bersama-sama dengan masyarakat.

Amandemen Undang-Undang Dasar Negara Republik Indonesia Tahun 1945 selanjutnya disingkat UUD 1945 pada Pasal 18 B ayat (2) dan Pasal 28 Ayat (3) menjelaskan "negara mengakui dan menghormati kesatuan-kesatuan masyarakat hukum adat beserta hak-hak tradisionalnya sepanjang masih hidup dan sesuai dengan perkembangan masyarakat dan prinsip negara kesatuan Republik Indonesia dan diatur dalam undang-undang selanjutnya Identitas

${ }^{19} \mathrm{I}$ b i d, $\operatorname{hlm} 7$ 
Budaya dan Hak Masyarakat Tradisional dihormati dan selaras dengan perkembagan zaman dan peradaban

Penunjukan suatu kawasan hutan konservasi oleh pemerintah ini kadangkala tidak sejalan dengan amanah konstitusi yaitu kesejahteraan bagi seluruh rakyat Indonesia terkhusus masyarakat hukum adat yang mendiami dan menerapkan kearifan local dalam wilayah tersebut. Akibat dari situsi tersebut muncul penolakan. Penolakan ini terjadi karena pengaturan tentang kawasan hutan di Indonesia tidak memperhatikan keberadaan dan hak-hak kesatuan masyarakat hukum adat atas wilayah adatnya. Padahal kesatuan masyarakat hukum adat mempunyai sejarah penguasaan tanah dan sumber dayanya sendiri yang berimbas pada perbedaan basis klaim dengan pihak lain termasuk Pemerintah (negara) terhadap kawasan hutan. Dalam kenyataannya, kesatuan masyarakat hukum adat belum memperoleh hak-hak yang jelas atas klaimnya tersebut, sebaliknya tidak jarang mereka justru dianggap sebagai pelaku kriminal ketika mereka mengakses kawasan hutan yang mereka akui sebagai wilayah adat. Pada sisi lain merupakan suatu kebanggaan bagi masyarakat adat yang mendiami kawasan tersebut karena kearifan lokal merekalah kawasan hutan itu memenuhi syarat untuk suatu kawasan hutan yaitu TNKM.

Negara yang tediri dari lembaga legislatif, yudikatif, dan eksekutif berwenang untuk menyelenggarakan negara dengan tujuan mensejahterahkan rakyat.Pemerintah menetapkan aturan dengan melihat situasi hukum serta niat baik negara dalam mengakomodir hak-hak warga negaranya. Mahkamah Konstitusi Republik Indonesia, berfungsi antara lain sebagai guardian dari constitutional rights\| setiap warga Negara Republik Indonesia. Mahkamah Konstitusi Republik Indonesia merupakan badan yudisial yang bertugas menjaga hak asasi manusia sebagai hak konstitusional dan hak hukum setiap warga Negara.

Kewenangan mahkamah konstitusi sebagaimana dijelaskan Pasal 24C ayat (1) Perubahan Ketiga UUD 1945 menyatakan: Mahkamah Konstitusi berwenang mengadili pada tingkat pertama dan terakhir yang putusannya bersifat final untuk menguji undang-undang terhadap UUD, memutus sengketa kewenangan lembaga negara yang kewenangannya diberikan oleh UUD, memutus pembubaran partai politik dan memutus perselisihan tentang hasil Pemilihan Umum

Mahkamah konstitusi berdasarkan Putusan No. 35/PUU-X/2012 terkait gugatan Aliansi Masyarakat Adat Nusantara (AMAN) terhadap Judicial Review Nomor 41 Tahun 1999 Tentang Kehutanan memutuskan bahwa Pasal 5 ayat (1) Undang-Undang Nomor 41 Tahun 1999 tentang Kehutanan (Lembaran Negara Republik Indonesia Tahun 1999 Nomor 167, Tambahan Lembaran Negara Republik Indonesia Nomor 3888) bertentangan dengan Undang-Undang Dasar Negara Republik Indonesia Tahun 1945 sepanjang tidak dimaknai “Hutan negara sebagaimana dimaksud pada ayat (1) huruf a, tidak termasuk hutan adat";. 
Keputusan Mahkamah Konstitusi ini menjadi dasar bagi masyarakat hukum adat sebagai aturan yang meluruskan kewenangan negara dalam mengelola hutan adat. Masyarakat adat yang memanfaatkan kekayaan alam TNKM wajib untuk dilindungi karena merekalah yang melindungi hutan serta tidak menggunakan hutan untuk dieksploitasi. Tanah merupakan bagian dari permukaan bumi oleh karena itu setiap hal yang berhubungan dengan tanah memilki manfaat secara sosial dan ekonomis. Dalam Hukum Adat, tanah merupakan milik yang sangat penting, hubungan antara manusia dengan tanah sangat erat yaitu tanah sebagai tempat manusia untuk menjalani dan melanjutkan kehidupannya.

Tanah sebagai tempat masyarakat hukum adat berdiam, tanah yang digunakan untuk menanam, tanah di mana mereka dimakamkan dan tempat pelindungan serta kuburan leluhurnya. Tanah adat merupakan milik dari masyarakat hukum adat yang telah dikuasai sejak dahulu. Tanah telah memegang peran vital dalam kehidupan dan penghidupan bangsa, serta pendukung suatu negara, yang dimana memiliki corak agraris. Negara yang rakyatnya berhasrat melaksanakan demokrasi yang berkeadilan sosial dalam pemanfaatan tanah untuk sebesar-besar kemakmuran rakyat.

Pengukuhan suatu kawasan hutan menurut UU No 41 Tahun 1999 tentang Kehutanan, adalah penunjukan, pematokan batas, pemetaan dan penetapan. Kini telah berjalan sampai kepada pemasangan patok berdasarkan kesepakatan yang telah diambil dari beberapa pertemuan yang cukup sulit. Sebuah surat tentang pembentukan team yang disampaikan kepada Bupati Kabupaten Nunukan dengan tembusan kepada banyak pihak salah satunya kepala desa. Hal ini lah yang memicu penolakan kepala-kepala adat besar masyarakat hukum adat di Krayan bahwa mereka tidak diberitahu dan dilibatkan, padahal mereka masih ada dan kedudukannya diakui oleh Pemerintah.

Hal ini menarik karena menimbulkan gejolak pada masyarakat, sehingga perlu dilakukan penelitian dengan isu hukum sebagai berikut: the recognition of traditional rights of indigenous and tribal communities and the recognition of local wisdom in the management of Kayan Mentarang National Park.

Using Legal research, dilakukan untuk mencari pemecahan atas isu hukum yang timbul. Hasil yang hendak dicapai adalah memberikan preskripsi mengenai apa yang seyogianya ${ }^{20}$. the normative juridical ${ }^{21}$ and customary law approaches ${ }^{22}$ that this method is expected to address the issue of law. Penelitian hukum normatif yaitu penelitian yang mengkaji ketentuan hukum positif tertulis secara sitematis terkait dengan pengaturan pengelolaan hutan, pemanfaatan hutan untuk kesejahtaraan dan pengelolaan hutan oleh masyarakat hukum adat. Penilitian

\footnotetext{
${ }^{20}$ Peter Mahmud, Penelitian Hukum (Jakarta: Kencana Prenada Media Group, 2009). 89

${ }^{21}$ Hadjon Philipus and Djatmiati Tatiek, Hadjon Philipus (Gajah Mada University, 2005). 1

${ }^{22}$ Soepomo, Bab-Bab Tentang Hukum Adat (Jakarta: Pradya Paramita, 2000). 30-31
} 
hukum adat adalah dengan menanyakan kepada kepala-kepala adat dan masyarakat setempat apa yang dialaminya dalam putusan adat dan apa yang diyakini masyarakat seharusnya menjadi pedoman.

Perlindungan hukum adalah memberikan pengayoman terhadap hak asasi manusia (HAM) yang dirugikan orang lain dan perlindungan itu diberikan kepada masyarakat agar dapat menikmati semua hak-hak yang diberikan oleh hukum ${ }^{23}$. Perlindungan hukum ${ }^{24}$ kepada masayarakat hukum adat dapat dibagi dalam dua aspek. Pertama yaitu perlindungan secara preventif yang bertarti mencegah hak-hak masyarakat hukum adat dilanggar oleh subyek hukum lain contohnya, memberikan kesempatan kepada masyarakat hukum adat untuk mengajukan keberatan (inspraak) atas suatu keputusan pemerintah yang belum definitve. Hal ini diperlukan untuk mencegah terjadinya sengketa dan memberikan pemerintah informasi penting dalam mengambil tindakan.

\section{DISKUSI}

\subsection{Pengakuan hak tradisional Masyarakat Hukum Adat}

Masyarakat hukum adat sebagai suatu kelompok masyarakat tradisional yang kini mendapat perhatian internasional yang dikenal sebagai indigenous people, di Indonesia bangkit kembali dalam pengaturan dan implementasinya. Masyarakat hukum adat menjadi subjek hukum yang tahap demi tahap diakui perannya, karena keberadaannya menunjukan peran yang sangat signifikan khususnya dalam perlindungan lingkungan hidup terutama hutan.

Tidak dipungkiri bahwa umumnya masyarakat hukum adat yang bertempat di kawasan hutan hidup dalam taraf yang memprihatinkan. Sebagai warga negara mereka berhak mendapat pemenuhan hak untuk hidup layak, dalam hal kesehatan, pendidikan dan kesejahteraan. Pada sisi lain hak tradisional mereka terampas oleh ketidakmampuan mereka mengurus diri sendiri, oleh pembangunan, dan juga oleh kepentingan umat manusia yang lebih luas.

Pengaturan tentang masyarakat hukum adat atau masyarakat adat sebagai subjek hukum mengalami pasang surut sesuai dengan perkembangan jaman. Konstitusi atau UUD 1945 mengakui keberadaan masyarakat hukum adat, bahkan setelah amendemen konstitusi, makin dipertegas lagi. Selanjutnya implementasi dalam peraturan perundang-undangan yang berkaitan lebih dikonkritkan, namun kadang kala tidak kompak. Sehingga memerlukan harmonisasi agar pengakuan keberadaan masyarakat hukum adat tersebut menjadi tuntas (tidak separuh hati) sehingga memberi kepastian dan manfaat nyata bagi masyarakat hukum adat.

\footnotetext{
${ }^{23}$ Salim S and Septiana Erlies Nurbani, Penerapan Teori Hukum Pada Penelitian Tesis Dan Disertasi, 2013. 259

${ }^{24}$ Philipus Hadjon, Pengatar Hukum Administrasi Indonesia (Introduction to the Indonesian Administrative Law) (Yogyakarta: Gadjah Mada University Press, 1993). 2-5
} 
Peraturan Menteri Negara Agraria/Kepala Badan Pertanahan Nasional Nomor 5 Tahun 1999 Tentang Pedoman Penyelesaian Masalah Hak Ulayat Masyarakat Hukum Adat, selanjutnya disingkat Permen Agraria No. 5 Tahun 1999, dalam Pasal 1 ayat 3 disebutkan: Masyarakat hukum adat adalah sekelompok orang yang terikat oleh tatanan hukum adatnya sebagai warga bersama suatu persekutuan hukum karena kesamaan tempat tinggal atau pun atas dasar keturunan.

Keberadaan masyarakat Hukum Adat (masyarakat adat) merupakan keniscayaan sehingga agar kehidupan bernegara menjadi tertib memerlukan pengaturan. Pengaturan masyarakat hukum adat lebih cenderung kepada pengakuan keberadaan tidak pada kegiatan sehingga menjadikan sebagai objek bukan subjek, sehingga tidak dapat bertindak hukum dan mendapat perlindungan hukum. Posisinya menunggu tergantung pada niat baik pemerintah. ${ }^{25}$

Secara terminologis, "pengakuan" (erkenning) berarti proses, cara, perbuatan mengaku atau mengakui, sedangkan kata "mengakui" berarti menyatakan berhak. Pengakuan dalam konteks ilmu hukum internasional, misalnya terhadap keberadaan suatu negara/pemerintahan biasanya mengarah pada istilah pengakuan de facto dan de yure. Pengakuan yang secara nyata terhadap entitas tertentu untuk menjalankan kekuasaan efektif pada suatu wilayah disebut dengan pengakuan de facto. Pengakuan de facto adalah pengakuan yang bersifat sementara, karena pengakuan ini ditunjukkan kepada kenyataan-kenyataan mengenai kedudukan pemerintahan yang baru, apakah ia didukung oleh rakyatnya dan apakah pemerintahannya efektif yang menyebabkan kedudukannya stabil. Jika kemudian bisa dipertahankan terus dan makin bertambah maju, maka pengakuan de facto akan berubah dengan sendirinya menjadi pengakuan de jure. Pengakuan de jure bersifat tetap yang diikuti dengan tindakan-tindakan hukum lainya. Sedangkan pengakuan secara hukum (de jure) adalah pengakuan suatu negara terhadap negara lain yang diikuti dengan tindakan-tindakan hukum tertentu, misalnya pembukaan hubungan diplomatik dan pembuatan perjanjian antar kedua negara ${ }^{26}$

Berdasarkan rujukan di atas, dalam kaitannya dengan pengertian pengakuan dan perlindungan terhadap masyarakat hukum adat atas tanah, maka pengakuan terhadap masyarakat hukum adat atas tanah mengarah pada pengertian pengakuan dari negara/pemerintah baik secara politik maupun secara hukum, melalui pengaturan hak dan kewajiban pemerintah dalam memberikan penghormatan, kesempatan dan perlindungan bagi berkembangnya masyarakat hukum adat beserta hak-hak tradisional yang dimiliki dalam bingkai Negara Kesatuan Republik Indonesia. Pengakuan tersebut menunjukkan bahwa negara/pemerintah telah mengakui, menyatakan sah/benar atau menyatakan masyarakat

\footnotetext{
${ }^{25}$ Marthin, "Prinsip Hukum Pengelolaan Hutan Pada Tanah Ulayat" (Airlangga, 2015). 166

${ }^{26}$ Husen Alting, Dinamika Hukum Dalam Pengakuan Dan Perlindungan Hak Masyarakat Hukum Adat Atas Tanah, (Musa Lalu, Kini Dan Masa Mendatang), (Yogyakarta: Penerbit LaksBang PRESSindo, 2011). 20
} 
hukum adat berhak atas sumberdaya alam yang dimiliki dan mewajibkan pemerintah untuk melindungi hak-hak tersebut dari ancaman/gangguan pihak lain. Pengakuan tersebut merupakan pengakuan yang diformulasikan dalam bentuk hukum negara terhadap hak masyarakat hukum adat atas tanah dan sumber daya alam lainnya. ${ }^{27}$

Masyarakat hukum adat diatur dalam Pasal 18 UUD NKRI 1945, dalam bab tentang pemerintahan daerah itu berarti mempunyai kewenangan dan wilayah, namun perbedaannya dengan wilayah propinsi terbagi atas kabupaten dan kota, tidak bersusun dengan lainnya. Namun Kesatuan masyarakat hukum adat dan wilayah hak ulayatnya tetap berada diatas wilayah Propinsi atau kabupaten atau kecamatan atau desa yang telah membagi habis wilayah Negara. Sehingga keberadaannya menunggu pengakuan dari Propinsi atau Kabupaten dimana terletak wilayah masyarakat hukum adat tersebut. Diundangkannya Undang-undang No. 6 Tahun 2014 tentang Desa (Lembaran Negara Republik Indonesia Tahun 2014 Nomor 7; Tambahan Lembaran Negara Republik Indonesia Nomor 5495), dalam Pasal 6 Ayat (1) dsebutkan: Desa terdiri atas Desa dan Desa Adat. Selanjutnya dalam Penjelasan pasal tersebut, Ketentuan ini untuk mencegah terjadinya tumpang tindih wilayah, kewenangan, duplikasi kelembagaan antara Desa dan Desa Adat dalam 1 (satu) wilayah maka dalam 1 (satu) wilayah hanya terdapat Desa atau Desa Adat. Untuk itu harus dipilih salah satu jenis Desa sesuai dengan ketentuan Undang-Undang ini.

Pasal 1 Permen Agraria No. 5 Tahun 1999, disebutkan, Hak ulayat dan yang serupa itu dari mesyarakat hukum adat (untuk selanjutnya disebut hak ulayat), adalah kewenangan yang menurut hukum adat dipunyai oleh masyarakat hukum adat tertentu atas wilayah tertentu yang merupakan lingkungan hidup para warganya untuk mengambil manfaat dari sumber daya alam, termasuk tanah, dalam wilayah tersebut, bagi kelangsungan hidup dan kehidupannya, yang timbul dari hubungan secara lahiriah dan batiniah turun menurun dan tidak terputus antara masyarakat hukum adat tersebut dengan wilayah yang bersangkutan.

Menurut Jeane N Saly, sebagaimana dikutip oleh Dominikus Rato, ${ }^{28}$ eksistensi masyarakat adat saat ini sangat memprihatinkan, khususnya berkaitan dengan hak-hak mereka terhadap hak atas tanah. Eksistensi masih rentan karena tergantung pada pengakuan dan selanjutnya hak tradisional yang melekat pada masyarakat adat pun mengalami perlakuan yang sama. Perjuangan untuk memperoleh hak ulayat tersebut adalah dengan membuktikan atau memenuhi persyaratan yang ditentukan oleh undang-undang.

Selanjutnya Dominikus Rato mengutip Baehr,,29 Masyarakat adat (Indegenous People), dengan mengutip laporan Komite Penasihat Hak Asasi Manusia dan Kebijakan Luar-negeri Belanda, menyatakan enam kriteria yang dianggap penting untuk menandai hak kolektif, yaitu:

\footnotetext{
${ }^{27}$ Alting.?

${ }^{28}$ Rato Dominikus, Pengantar Hukum Adat (Yogyakarta: Laksbang Pressindo, 2009). 124-125

${ }^{29}$ Rato Dominikus. Op Cit h.126
} 
(i) hak kolektif harus mempunyai obyek hak yang menentukan isi dari hak itu; (ii) harus mempunyai subyek (pemegang/pemilik) hak yang dapat menuntut hak itu; (iii) harus ditujukan pada satu pemegang kewajiban terhadap siapa hak itu bisa dituntut; (iv) pendakuan (tuntutan) haruslah esensial bagi satu keberadaan yang bermartabat; (v) tuntutan itu bukanlah sesuatu yang dapat diindividualisasikan; dan (vi) tuntutan itu haruslah memperkuat pelaksanaan hak asasi manusia individual, dan dalam keadaan apapun tidak boleh mengecilkan hak asasi manusia. Selanjutnya Baehr menyatakan bahwa kolektivitas haruslah memiliki hak asasi manusia, bilamana hak itu hanya dapat dimiliki oleh kolektivitas dan tidak dapat direduksi pada hak-hak individual. Hak-hak yang memenuhi persyaratan sebagai hak kolektit kata Baehr, adalah: hak menentukan nasib sendiri (right to self determination), hak bebas dari genosida, hak rakyat atas pembangunan dan untuk mengakses ke sumber-daya. Hak kolektif lain adalah hak untuk melestarikan atau melindungi kebudayaan sendiri, pelarangan diskriminasi rasial, agama dan/atau bahasa, hak 'indigenous peoples', dan hak kaum minoritas. Kriteria keenam menjadi penting untuk memecahkan kemungkinan bentrokan antara hak individual anggota `masyarakat (hukum) adat' dengan hak kolektifnya. Manakala bentrokan itu terjadi, kriteria keenam ini memberikan panduan untuk memecahkan dilema etis yang dihadapi oleh 'masyarakat (hukum) adat yaitu tetap harus memprioritaskan penegakan hak asasi manusia individual, dan/atau mendudukkan posisi hak asasi manusia individual di atas hak kolektif. Upacara adat memenggal kepala manusia (misalnya tradisi 'ngayau' di masyarakat Dayak) tidaklah bisa dijadikan legitimasi hak kolektif, karena akan mengancam hak asasi manusia yang paling inti (hard core) dan paling dasar (fundamental) dan bersifat non-derogable, yakni hak untuk hidup atau paling tidak merupakan tindakan mendudukan hak kolektif di atas hak asasi manusia individual.

Pengaturan tentang masyarakat hukum adat dalam hubungannya dengan hutan lingkungan hidupnya (hak tradisional) sebagai kawasan hutan konservasi atau hutan lindung, khusus di TNKM, mengalami dinamika perkembangan yang dapat dirinci sebagai berikut:

1. Penetapan sebagai kawasan hutan

Menteri Pertanian No. 84/Kpts/Um/II/1980, Tanggal 25 November 1980, serta berdasarkan Undang-undang No. 5 Tahun 1967 tentang pokok-pokok kehutanan, ditetapkan sebagai cagar alam. Selanjutnya Keputusan Menteri Kehutanan No. 631/Kpts-II/1996, tanggal 7 Oktober 1996 dan berdasarkan Undang-undang No. 5 Tahun 1990 tentang Konservasi Sumber Daya Alam Hayati dan Ekosistemnya ditunjuk sebagai TNKM.

2. Pasca Amendemen UUD 1945 [vide Pasal 18B ayat (2) Pengakuan terhadap Masyarakat Hukum adat dan hak tradisionalnya.

Selanjutnya dijabarkan di berbagai Undang-Undang selain UU Kehutanan; Undang-Undang Nomor 39 Tahun 1999 tentang Hak Asasi Manusia; Undang-Undang Nomor 23 Tahun 2014 
tentang Pemerintahan Daerah; Undang-Undang Nomor 6 Tahun 2014 tentang Pemerintahan Desa; Undang-Undang Nomor 31 Tahun 2004 tentang Perikanan; dan Undang-Undang Nomor 27 Tahun 2007 tentang Pengelolaan Wilayah Pesisir dan Pulau-Pulau Kecil;

3. Peraturan Daerah tentang keberadaan Masyarakat Hukum Adat

Peraturan Daerah Kabupaten Nunukan Nomor 04 Tahun 2004 Tentang Hak Ulayat Masyarakat Hukum Adat Lundayeh Kabupaten Nunukan (Lembaran Daerah Kabupaten Nunukan Tahun 2004 Nomor 11 Seri E Nomor 04). Selanjutnya disebut Perda No. 04 Tahun 2004.

4. Keputusan Mahkamah Konstitusi Nomor 35/PUU-X/2012

Kata "negara" dalam Pasal 1 angka 6 Undang-Undang Nomor 41 Tahun 1999 tentang Kehutanan (Lembaran Negara Republik Indonesia Tahun 1999 Nomor 167, Tambahan Lembaran Negara Republik Indonesia Nomor 3888) tidak mempunyai kekuatan hukum mengikat, sehingga Pasal 1 angka 6 Undang-Undang Nomor 41 Tahun 1999 tentang Kehutanan dimaksud menjadi "Hutan adat adalah hutan yang berada dalam wilayah masyarakat hukum adat";

5. Pematokan TNKM dan Pemberian hak kelola kehutanan kepada masyarakat hukum adat

Berbagai peraturan yang memberi petunjuk pengakuan dan penyelesaian hak atas tanah dan hutan masyarakat hukum adat. Peraturan Menteri Dalam Negeri Nomor 52 Tahun 2014 Tentang Pedoman Pengakuan Dan Perlindungan Masyarakat Hukum Adat, Peraturan Menteri Lingkungan Hidup Dan Kehutanan Republik Indonesia Nomor : P.32/Menlhk-Setjen/2015 Tentang Hutan Hak, Peraturan Presiden Republik Indonesia Nomor 88 Tahun 2017 Tentang Penyelesaian Penguasaan Tanah Dalam Kawasan Hutan,

Pada saat penunjukan sebagai kawasan cagar alam, masyarakat hukum adat yang mendiami daerah tersebut hanya tahu, namun tidak mengerti perihal semua itu. Karena dari dahulu masyarakat tidak pernah berfikir tentang pengelolaan hutan oleh pihak lain selain masyarakat itu sendiri. Berbagai upaya untuk memasuki wilayah hidup mereka dengan tujuan mengambil kayu atau apa yang ada dalam wilayah mereka seperti gaharu, tidak dijinkan.

Perubahan status dari cagar alam menjadi taman nasional, sedikit demi sedikit dipahami, dan tidak berbeda dengan apa yang mereka lakukan dengan hutan lingkungannya. Peran pemerintah melakukan sesuatu yang sesuai dengan apa yang mereka lakukan dan pertahankan mendapat response positif dan dapat diterima. Dengan dukungan dan support dari lembaga WWF masyarakat mulai melakukan hal yang berbeda dari kebiasaan ladang berpindah, pindah kampung yaitu menetap dengan membuat sawah seperti kebiasaan dari sebagian kelompok lain masyarakat tersebut. 
Hutan adat adalah hutan negara yang berada di wilayah masyarakat hukum adat sebagai hukum yang dipahami mereka tentang status kawasan hutan adat yang mereka jaga. Hutan adat adalah hutan dari masyarakat hukum adat tersebut, walaupun disebut sebagai hutan negara, tidak menjadi masalah karena negara juga tidak pernah hadir. Mereka membuat hukum untuk melindungi hutannya dari gangguan anggota masyarakatnya dan orang luar, baik terhadap hutan, membuka hutan tanpa persetujuan bersama, mengambil kekayaan hutan, termasuk binatang dan tumbuhan dari hutan. Seperti membakar ladang yang berakibat meluas ke hutan dikenakan denda. orang luar mengambil gaharu dihukum dan gaharunya disita. Mengambil burung yang dilindungi, dikenakan denda dan burungnya dilepas. Hukum adat yang mereka bina menunjukan bagaimana mayarakat melindungi hutan dan kekayaannya. Layaknya melaksanakan tugas negara melindungi hutan.

Tahun 2007 salah satu pertemuan Kesepakatan bersama Pertemuan Konsultasi publik Tata batas TNKM di Long Bawan tanggal 19 Januari 2007 diambil kesepakatan tentang wilayah hutan adat yang dijadikan taman nasional dengan status zona tradisional dan zona inti serta zona lainnya, tertuang dalam berita acara. Kesepakatan dalam Poin 3. Wilayah yang oleh masyarakat disebut sebagai hutan adat, tetap dipertahankan sebagai Zona Tradisional, yang pengelolaannya ditentukan secara musyawarah untuk kepentingan bersama (Masyarakat dan Pemerintah). Yang dimaksud dengan Zona Tradisonal menurut Peraturan Menteri Kehutanan No. P.56/MenhutII/2006 tanggal 29 Agustus 2006 tentang Zonasi Taman Nasional, adalah bagian dari Taman Nasional Kayan Mentarang yang ditetapkan untuk kepentingan pemanfaatan tradisonal oleh masyarakat yang karena kesejarahan mempunyai ketergantungan dengan sumber daya alam.

Dari pertemuan tersebut dan pertemuan lanjutan mulai nampak penolakan dari sebagian warga masyarakat yang memahami taman nasional diatur oleh negara bukan oleh adat lagi. Padahal menurut masyarakat, hutan adat diperuntukan untuk sumber penghidupan sehari-hari, daerah pengaman, perkembangan kampung, tempat membuka kampung baru bila tempat yang ada sudah tidak memadai mendukung kehidupan kampung.

Kegiatan pihak balai kehutanan mematok batas pada daerah yang masih jelas aktivitas kehidupan masyarakat, seperti tempat penggembalaan ternak, bahkan sawah milik masyarakat, menjadi pemicu penolakan semakin kuat. Penolakan masih berkisar pada luas. Kami yang menjaga dan memelihara, kehutanan mengklaim, menjadi sesuatu yang melukai perasaan masyarakat yang disampaikan kepada pemerintah daerah dan pusat.

Tahun 2012 Putusan Mahkamah Konstitusi yang mengabulkan tuntutan uji materi terhadap UU No. 41 tahun 1999 tentang Kehutanan, dengan putusan hutan adat adalah hutan yang berada di wilayah masyarakat hukum adat, menjadi landasan masyarakat untuk menolak 
kesepakatan sebelumnya. Sudah berkembang, bukan saja masalah luas, namun sebaliknya minta pengakuan terlebih dahulu, baru masuk kepada luas yang disetujui.

Sampai kepada nama taman nasional yaitu kayan mentarang pun menjadi tuntutan. Apa yang salah? Nama Taman Nasional Kayan Mentarang, bahwa nama kayan mentarang diambil dari dua sungai kayan dan mentarang. Sungai Mentarang hanya sepotong sungai diwilayah Mentarang, hulunya sungai Krayan, hilirnya sungai Tubu dan sungai Sesayap. Sebuah sungai yang memiliki nama begitu banyak. Apalah arti sebuah nama? Mengapa tanah Krayan habis ditunjuk sebagai taman nasional, sedangkan mentarang yang punya nama sedikit. Mengapa disebut mentarang? Wilayahnya yang salah. Harusnya di Mentarang itu bukan di Krayan. Demikian suara yang muncul di daerah Krayan. Apakah suara ini perlu ditelisik lebih lanjut, karena berkaitan dengan penolakan masyarakat atas penunjukan tersebut?

Perda No. 4 Tahun 2004, dalam Pasal 3 menyebutkan, Masyarakat hukum adat Lundayeh di Kecamatan Krayan dibagi atas :

a. Masyarakat Hukum Adat Krayan Hulu;

b. Masyarakat Hukum Adat Krayan Tengah;

c. Masyarakat Hukum Adat Krayan Darat;

d. Masyarakat Hukum Adat krayan Hilir.

Masyarakat hukum adat masing-masing dipimpin oleh Kepala Adat Besar. Kepala Adat Besar dalam melaksanakan tugasnya dibantu oleh Kepala Adat Desa yang tergabung dalam masing-masing kelompok masyarakat hukum adat.

Selanjutnya dalam Pasal 4, Penegasan Batas-Batas Wilayat Adat Masyarakat Hukum Adat sebagaimana dimaksud mempunyai batas-batas sebagai berikut :

a. Masyarakat Hukum Adat Krayan Hulu :

1. Sebelah Utara berbatasan dengan Wilayah Adat Krayan Darat;

2. Sebelah Timur berbatasan dengan Wilayah Adat Krayan Tengah;

3. Sebelah Selatan berbatasan dengan Kabupaten Malinau;

4. Sebelah Barat berbatasan dengan Serawak (Malaysia);

b. Masyarakat Hukum Adat Krayan Tengah :

1. Sebelah Utara berbatasan dengan Wilayah Adat Krayan Hilir;

2. Sebelah Timur berbatasan dengan Kabupaten Malinau;

3. Sebelah Selatan berbatasan dengan Wilayah Adat Krayan Hulu;

4. Sebelah Barat berbatasan dengan Wilayah Adat Krayan Darat;

c. Masyarakat Hukum Adat Krayan Darat :

1. Sebelah Utara berbatasan dengan Wilayah Adat Krayan Hilir;

2. Sebelah Timur berbatasan dengan Wilayah Adat Krayan Tengah;

3. Sebelah Selatan berbatasan dengan Wilayah Adat Krayan Hulu; 
4. Sebelah Barat berbatasan dengan Serawak (Malaysia);

d. Masyarakat Hukum Adat Krayan Hilir :

1. Sebelah Utara berbatasan dengan Sabah (Malaysia);

2. Sebelah Timur berbatasan dengan Kecamatan Lumbis;

3. Sebelah Selatan berbatasan dengan Wilayah Adat Krayan Darat ;

4. Sebelah Barat berbatasan dengan Serawak (Malaysia);

Penetapan Batas dalam Perda No 4 Tahun 2004 berdasarkan batas administrasi wilayah Kecamatan Krayan di Kabupaten Nunukan. Karena Penduduk Kecamatan Krayan seluruhnya merupakan Masyarakat Hukum Adat Lundayeh, maka ditetapkan demikian sesuai dengan kewenangan pemerintah daerah kabupaten. Batas luar adalah Kabupaten Malinau, Serawak dan Sabah Malaysia sebenarnya juga berbatas dengan masyarakat adat Lundayeh. Namun mereka tidak mendapat kesempatan yang sama dengan Kecamatan Krayan Kabupaten Nunukan. Di Serawak mendaftarkan identitas mereka dengan nama Lun Bawang. ${ }^{30}$

Lebih lanjut penetapan batas tersebut, dalam pasal 5,6,dan 7, harus dilakukan dinas yang berwenang dan sudah ditetapkan dalam waktu 2 (dua) tahun. Namun hal itu ternyata tidak dapat diselesaikan. Hal ini berhubungan dengan apa yang diatur dalam Pasal 10 tentang pengecualian yang tidak dimasukan ke dalam hak ulayat, seperti hak perorangan atau badan hukum sesuai peraturan perundangan yang berlaku dan merupakan bidang-bidang tanah yang sudah diperoleh atau dibebaskan oleh Instansi Pemerintah, badan hukum atau perseorangan sesuai ketentuan dan tata cara yang berlaku. Dalam hal ini sudah tentu termasuk TNKM.

Pemerintah tetap konsekuen memberi perlindungan kepada rakyatnya, hanya kapan. Beberapa peraturan perundang-undangan sebagai peraturan pelaksana diterbitkan pemerintah dalam berbagai jenjang sesuai kewenangannya, Seperti Peraturan Menteri Dalam Negeri Nomor 52 Tahun 2014 Tentang Pedoman Pengakuan Dan Perlindungan Masyarakat Hukum Adat. Merupakan kelanjutan dari peraturan-peraturan sebelumnya tentang hak ulayat dan masyarakat hukum adat.

Peraturan Menteri Lingkungan Hidup Dan Kehutanan Republik Indonesia Nomor: P.32/Menlhk-Setjen/2015 Tentang Hutan Hak, dan Peraturan Presiden Republik Indonesia Nomor 88 Tahun 2017 Tentang Penyelesaian Penguasaan Tanah Dalam Kawasan Hutan. Keduanya merupakan petunjuk teknis penyelesaian masalah tanah dan hutan adat berhubungan dengan kawasan hutan. Dasar menimbang dari peraturan tersebut yang pertama adalah Keputusan Mahkamah Konstitusi nomor 35 Tahun 2012.

\footnotetext{
${ }^{30}$ Marthin, “Prinsip Hukum Pengelolaan Hutan Pada Tanah Ulayat.”, 254
} 
Sebagai bukti dua buah contoh keputusan pemerintah yang memberi legalitas atau surat keputusan tentang hutan adat yaitu Keputusan Menteri Lingkungan Hidup dan Kehutanan Republik Indonesia Nomor: SK 6745/MENLHK-PSKL/KUM.I/12/2016 tentang Penetapan Hutan Adat Marga Serampas Seluas \pm 24 (dua puluh empat) hektar di Desa Rantau Kermas Kecamatan Jangkat Kabupaten Merangin Provinsi Jambi. Menetapkan Hutan Adat Marga Serampas Seluas \pm 24 (dua puluh empat) herkar di Desa Rantau Kermas Kecamatan Jangkat Kabupaten Merangin Provinsi Jambi, dari Hutan Konservasi di Taman Nasional Kerinci Seblat menjadi hutan hak bagi masyarakat hukum adat Marga Serampas, Desa Rantau Kermas Kecamatan Jangkat Kabupaten Merangin Provinsi Jambi. Dengan kewajiban tetap mempertahankan sebagai hutan dan tidak boleh diperjualbelikan. Mendapat dukungan dan perlindungan dari Pemerintah. Selanjutnya Keputusan Menteri Lingkungan Hidup dan Kehutanan Republik Indonesia Nomor: SK 6746/MENLHK-PSKL/KUM.I/12/2016 tentang Penetapan Hutan Adat Ammatoa Kajang seluas \pm 313,99 (Tigaratus tiga belas dan sembilan puluh sembilan perseratus) Hektar di Kecamatan Kajang Kabupaten Bulukumba Provinsi Sulawesi Selatan. Dari kawasan hutan produksi tetap menjadi Hutan hak dengan fungsi pokok lindung. Hal ini menunjukan keseriusan pemerintah mengatur dan melindungi masyarakat hukum adat dan hak tradisionalnya.

\subsection{Pengakuan Kearifan Lokal dalam Pengelolaan Taman Nasional Kayan Mentarang}

Sejak beberapa dekade yang lalu, pemanasan global telah menjadi isu global. Kerusakan hutan, khususnya hutan hujan tropis erat kaitannya dengan isu global tersebut. Kesadaran untuk melestarikan alam tersebut diwujudkan dalam tindakan nyata dengan dimasukkannya ketentuan-ketentuan mengenai hal itu ke dalam peraturan perundang-undangan yang mengatur tentang sumber daya alam. Pendayagunaan sumber daya alam diarahkan untuk tetap memperhatikan keseimbangan lingkungan hidup agar tetap lestari fungsinya sehingga dapat memberikan manfaat sebesar-besarnya bagi kesejahteraan rakyat dan bisa dimanfaatkan oleh generasi mendatang.

Hutan sebagai modal pembangunan nasional memiliki manfaat yang nyata bagi kehidupan dan penghidupan bangsa Indonesia, baik manfaat ekologi, sosial budaya maupun ekonomi, secara seimbang dan dinamis. Untuk itu hutan harus diurus dan dikelola, dilindungi dan dimanfaatkan secara berkesinambungan bagi kesejahteraan masyarakat Indonesia, baik generasi sekarang maupun yang akan datang. ${ }^{31}$

Kerusakan hutan yang terjadi di dunia khususnya di Indonesia merupakan akibat perbuatan manusia, disamping itu ada kearifan dalam berinteraksi dengan alam yang melindungi.

\footnotetext{
${ }^{31}$ Marthin, Yahya Zein, and Arif Rohman, "Problematika Penetapan Kawasan Hutan Di Wilayah Masyarakat Adat Dalam Rangka Pembangunan Berkelanjutan Di Kota Tarakan,” Jurnal Pandecta 9, no. 1 (2014).
} 
Awalnya kearifan itu berupa pemahaman yang 'religius magis', namun kemudian berubah menjadi pemahaman yang memandang alam sebagai sumber kehidupan sehingga perlu dijaga dan dilestarikan. Kearifan ini sering disebut sebagai kearifan lokal.

Kearifan lokal didefinisikan sebagai kebenaran yang telah mentradisi atau ajeg dalam suatu daerah. Kearifan lokal atau sering disebut local wisdom dapat dipahami sebagai usaha manusia dengan menggunakan akal budinya (kognisi) untuk bertindak dan bersikap terhadap sesuatu, objek, atau peristiwa yang terjadi dalam ruang tertentu. Kearifan (wisdom) secara etimologi berarti kemampuan seseorang dalam menggunakan akal pikirannya untuk menyikapi sesuatu kejadian, obyek atau situasi. Sedangkan lokal, menunjukkan ruang interaksi dimana peristiwa atau situasi tersebut terjadi. Dengan demikian, kearifan lokal secara substansial merupakan norma yang berlaku dalam suatu masyarakat yang diyakini kebenarannya dan menjadi acuan dalam bertindak dan berperilaku sehari-hari. Oleh karena itu, kearifan lokal merupakan entitas yang sangat menentukan harkat dan martabat manusia dalam komunitasnya. 32

Kearifan lokal dikonsepsikan sebagai pengetahuan setempat (local knowledge), kecerdasan setempat (local genius), dan kebijakan setempat (local wisdom), oleh UU RI No. 32 Tahun 2009 tentang Perlindungan dan Pengelolaan Lingkungan Hidup diartikan sebagai nilai-nilai luhur yang berlaku dalam tata kehidupan masyarakat yang antara lain dipakai untuk melindungi dan mengelola lingkungan hidup secara lestari. ${ }^{33}$

Secara substantif pokok-pokok isi kearifan lokal mencakup tiga kategori: ${ }^{34}$ 1) kategori tentang lingkup kearifan lokal yang terdiri atas: konsep-konsep, folklor, ritual, kepercayaan, beragam pantangan dan anjuran, nilai, filosofi, idiologi; 2) kategori tentang metode dan cara-cara mengedepankan kearifan dan kebijakan yang meliputi dedikasi, etika, humanis, rasional, rasa, dan makna; 3) kategori tentang arah dan tujuan yang ingin diwujudkan, seperti keberlanjutan dan kelestarian alam, penguatan jati diri, masyarakat susila, keseimbangan dan harmoni, pengokohan spiritual, penghematan sumber daya, toleransi, dan perlindungan hak-hak lokal.

Kearifan lokal biasanya terwujud dalam bentuk filosofi, nilai, norma, hukum adat, etika, lembaga sosial, sistem kepercayaan melalui upacara. Bentuk kearifan lokal secara lebih rinci terdapat pada berbagai aspek kehidupan, seperti bidang politik, ekonomi, sosial, budaya, pertanian, upacara, dan lain-lain. ${ }^{35}$ Berikut ini dapat disebutkan kearifan lokal dari wilayah Adat Hulu Sungai Bahau dan kearifan lokal masyarakat hukum adat Lundayeh Krayan.

\footnotetext{
${ }^{32}$ Imam S Ernawi, "Harmonisasi Kearifan Lokal Dalam Regulasi Penataan Ruang," IBDA 5, no. 1 (2007): 27-38.

${ }^{33}$ Marthin, "Prinsip Hukum Pengelolaan Hutan Pada Tanah Ulayat.", 185

${ }^{34}$ Griya, "Kearifan Lokal Dalam Perspektif Kajian Budaya Pergulatan Teoritik Dan Ranah Aplikatif (Program Magister Kajian Budaya" (Udayana, 2004). 5

${ }^{35}$ S Swarsi, “, Fungsi Kearifan Lokal Dalam Pembangunan Kualitas Sumber Daya Manusia (Laporan
} 
Masyarakat adat Wilayah Hulu Sungai Bahau, ${ }^{36}$ Kabupaten Malinau, Propinsi Kalimantan Utara. Mengatur hutan berdasarkan hukum adat lokal. Sifat hukum adat yang tidak statis, mulai dilakukan secara tertulis berdasarkan kesepakatan pada waktu Pesta Panen Gabungan dan Musyawarah Adat Besar Hulu Sungai Bahau. Setiap tahun atau lima tahun sekali dilakukan revisi berdasarkan perkembangan. Pemanfaatan dan Pengelolaan hutan dikenal Konsep Tana' Ulen (Sungai Ulen) adalah suatu kawasan hutan rimba yang dilindungi secara adat. Wilayah Tana ulen meliputi satu sungai atau beberapa sungai kecil mulai dari muara sampai keujung-ujung anak sungai di titik mata airnya. Batas-batas tana ulen meliputi punggung-punggung gunung dimana sungai tersebut mengalir. Di dalam wilayah tana ulen orang dilarang menebang pohon, membakar hutan, membuat ladang, dan kegiatan yang menimbulkan kerusakan hutan. Pengambilan hasil hutan di dalam tana ulen diatur hanya untuk beberapa jenis hasil hutan tertentu saja. Misalnya gaharu, rotan, kayu manis, ikan dan binatang. Tana ulen hanya dapat dimanfaatkan pada masa-masa tertentu saja, untuk kepentingan umum, berdasarkan kesepakatan pemuka-pemuka desa yang meliputi kepala adat desa, kepala desa, dan kepala adat besar.

Masyarakat hukum adat Lundayeh di Krayan hidup dalam wilayah yang sangat terisolir, ditengah hutan luas, membina kehidupan yang nyaman, aman, dan tertib dengan adat dan hukum adat yang menjadi pedoman. Hukum adat yang hidup sesuai dengan kondisi dan perkembangan masyarakat. Yang baru dipakai yang usang dibuang sebagaimana pepatah adat yang dikenal.

Masyarakat Hukum adat Lundayeh di Krayan ${ }^{37}$ terbagi dalam 5 (lima) kecamatan mengikuti perkembangan wilayah adat, yaitu Krayan, Krayan Barat, Krayan Timur, Krayan Selatan, dan Krayan Tengah. Namun Hukum adat yang ada masih hidup terkelompok menjadi 3 (tiga) yaitu: Hukum adat Krayan Darat untuk wilayah Krayan dan Krayan Barat, Hukum adat Krayan Hilir untuk Wilayah Krayan Timur, dan Hukum Adat Lon Taw berlaku di Krayan Selatan dan Krayan Tengah.

Hukum adat dari masyarakat hukum adat itu berkembang masing-masing sesuai dengan kebutuhan dan perkembangan masyarakatnya. Walaupun demikian diantara ketiga hukum adat yang ada tidak berbeda atau tidak jauh berbeda mengatur masalah yang sama. Namun sesuatu yang diatur oleh masyarakat Hukum adat yang satu belum tentu diatur oleh lainnya. Hal ini karena masalah tersebut tidak ada atau sangat jarang terjadi dimasyarakat tersebut. Bila kemudian terjadi, maka mereka mengadopsi dari hukum adat lainnya.

Penelitian, Balai Kajian Sejarah Dan Nilai Tradisional Denpasar" (Denpasar, 2004). 33

${ }^{36}$ Dkk Uluk Asung, "Ketergantungan Masyarakat Dayak Terhadap Hutan Di Sekitar Taman Nasional

Kayan Mentarang" (Taman Nasional Kayan Mentarang, 2001)., 79-86

${ }^{37}$ kepala-kepala adat Besar, "Pertanian Organik" (Long Bawan, 2017). 
Berkaitan dengan lingkungan hidup, mereka mengatur diantaranya: mengenai wilayah, sungai, hutan, binatang, dan tumbuhan dalam kegiatan masyarakat atau oleh orang luar. Wilayah adat ditentukan berdasarkan wilayah kampung (bawang). Batas antara dua kampung ditandai oleh batas kepemilikan garapan, misalnya sawah, ladang, kebun, dan tempat penggembalaan. Namun untuk hutan, kebiasaan yang ada sampai dimana kegiatan dari masyarakat kampung tersebut. Dapat terjadi overlapping, untuk hal ini kebiasaan masyarakat menentukan ditengahnya.

Di atas wilayah adatnya diatur semua hal yang berkaitan kegiatan yang boleh dan dilarang. Dahulu terhadap sungai ada penguasaannya dalam hal hak untuk menuba ikan. Menuba untuk kepentingan umum, namun kapan dan dimana boleh menuba diputuskan oleh pemilik. Setiap peserta akan memberikan seekor ikan besar kepada pemilik. Kini adat Lon Taw mengenakan denda terhadap kegiatan perorangan seperti meracuni dan menyetrum ikan di sungai didenda sebesar Rp 300.000,- (tiga ratus ribu rupiah) seseorang. Mengambil rotan di daerah adat lain didenda Rp 50.000.- (lima puluh ribu rupiah), mengambil kayu gaharu di wilayah lain atau wilayah adat tetangga didenda sebesar Rp 300.000,- (tiga ratus ribu rupiah) seseorang dan kayu gaharu disita. Sebaliknya bagi orang luar yang mengambil rotan didalam wilayah Masyarakat Adat Lon Taw Sungai Krayan, dikenakan denda adat sebesar Rp 2.000.000,- (Dua juta rupiah) untuk setiap orang dan semua rotan disita. Orang luar yang mengambil kayu Gaharu dalam wilayah Masyarakat Adat Lon Taw Sungai Krayan dikenakan denda adat sebesar Rp 2.000.000,- (Dua juta rupiah) dan semua kayu gaharu disita. Mengambil atau membunuh burung langka yang dilindungi adat, dikenakan denda adat sebesar Rp 2.000.000,- (Dua juta rupiah) untuk setiap ekornya dan burung disita kemudian burung yang masih hidup dilepas. Pembakaran hutan atau ladang atau kebun-sehingga menyebabkan. kebakaran daerah yang luas dikenakan denda adat sebesar Rp 2.500.000,- (Dua juta lima ratus ribu rupiah).

Masyarakat hukum adat membina hukum adat untuk melindungi lingkungan hidupnya agar dapat melindungi masyarakat dan dimanfaatkan berkelanjutan sampai generasi berikut. Hukum adat Lundayeh terbuka untuk menerima norma hukum dari luar yang memperkaya budaya dan hukum adat. Seperti dahulu ternak kerbau hidup bebas, sawah dipagar. Sekarang ternak dipagar agar juga tidak mengotori kampung layaknya aturan yang berlaku di kota.

Melalui beberapa pertemuan dan berbagai kesempatan, masyarakat Adat Dayak sudah sejak lama menyampaikan tuntutan Pemerintah Pusat dan Daerah, WWF, serta pihak-pihak terkait dengan pengelolaan hutan dan sumber daya alam lainnya agar hak-hak masyarakat adat atas tanah (wilayah adat) yang secara turun temurun mereka huni serta hak untuk mengelola dan memanfaatkan sumber daya alam yang terdapat di dalam wilayah adat mereka diakui, dihormati, dan dilindungi. Masyarakat adat memiliki keinginan yang kuat untuk ikut bertanggungjawab penuh dalam mengelola TNKM yang berkelanjutan dan menyejahterakan masyarakat. 


\section{Kebijakan Kolaboratif dalam pengelolaan hutan}

TNKM berada di wilayah adat Masyarakat hukum adat dayak. Suatu penghormatan yang diberikan terhadap lingkungan hidup masyarakat hukum adat dayak yang masih alami, sudah jarang ditemui diwilayah lain. Kebanggan itu bagaikan kutukan, meminjam istilah Richard Auty, bagi masyarakat dayak yang wilayah hidupnya dibatasi oleh aturan Taman nasional.

Pasal 1 angka (14) Undang-Undang Nomor 5 Tahun 1990 tentang Konservasi Sumber Daya Alam Hayati dan Ekosistemnya, disebutkan, "Taman national adalah kawasan pelestarian alam yang mempunyai ekosistem asli, dikelola dengan sistem zonasi yang dimanfaatkan untuk tujuan penelitian, ilmu pengetahuan, pendidikan, menunjang budidaya, pariwisata, dan rekreasi. Rumusan dalam Peraturan Perundangan/ PP No.28 Tahun 2011,” Kawasan Taman Nasional adalah kawasan pelestarian alam yang mempunyai ekosistem asli dikelola dengan sistem zonasi yang dimanfaatkan untuk tujuan penelitian, ilmu pengetahuan, pendidikan, menunjang budidaya, pariwisata, dan rekreasi." Selanjutnya dalam Permenhut No. P.56/Menhut- II/2006 menyebutkan,"Taman nasional adalah kawasan pelestarian alam baik daratan maupun perairan yang mempunyai ekosistem asli, dikelola dengan sistem zonasi yang dimanfaatkan untuk tujuan penelitian, ilmu pengetahuan, pendidikan, menunjang budidaya, budaya, pariwisata dan rekreasi."

Suatu pembatasan ruang gerak masyarakat hukum adat dayak dalam beraktivitas pada hutan lingkungannya. Terdapat 11 (sebelas) wilayah adat yaitu: Krayan Hulu, Krayan Tengah, Krayan Hilir, Krayan Darat, Pujungan, Hulu Bahau, Mentarang Hulu, Lumbis Hulu, Tubu, Apau Kayan-Kayan Hilir dan Kayan Hulu. Dihuni oleh warga suku Dayak dari 6 sub-suku Dayak yaitu suku Kenyah, Lundayeh, Abai/Tagel, Sa'ban, Punan dan Kayan.

TNKM ditetapkan pertama kali sebagai Cagar Alam oleh Menteri Pertanian RI Tahun 1980 (SK No. 84/Kpts/Un/II/1980 tanggal 25 November) Nama Kayan Mentarang diambil dari nama daerah aliran sungai (DAS) penting yang ada di kawasan taman nasional, yaitu DAS Kayan di bagian selatan dan DAS Mentarang di bagian utara. Kemudian, untuk menampung aspirasi masyarakat lokal (adat) dan berdasarkan kajian ilmiah, kawasan ini diubah statusnya menjadi Taman Nasional agar kepentingan masyarakat lokal dapat tertampung (SK Menteri Kehutanan No. 631/Kpts-II/1996 tanggal 7 Oktober). ${ }^{38}$

Menyadari akan tingginya nilai kekayaan alam dan budaya dari Kayan Mentarang, Pemerintah Indonesia menetapkan kawasan ini sebagai cagar alam pada tahun 1980. Manfaat sistem kawasan lindung Indonesia telah ditegaskan dalam Rencana Konservasi Nasional (FAO

\footnotetext{
${ }^{38}$ Wikipedia, “Taman Nasional Kayan Mentarang,” id.wikipedia.org, 2018.
} 
1982/83) dan nilai pentingnya diantara kawasan lindung di Asia telah didokumentasikan oleh IUCN (Mac Kinnon and Mac Kinnon, 1986) dan kemudian dipertegas pada laporan terbaru (Mac Kinnon, 1997). Kayan Mentarang ditetapkan sebagai taman nasional pada tahun 1996. Alasan utama dari perubahan status kawasan ini adalah karena taman nasional memberikan kemungkinan diteruskannya kegiatan pemungutan hasil hutan pada zona tertentu oleh masyarakat setempat secara tradisional yang telah bergantung pada hutan yang ada di kawasan tersebut selama berabad-abad, sementara dalam cagar alam hal ini tidak dimungkinkan. WWF telah bekerja bersama-sama dengan Departemen Kehutanan sejak tahun 1990 untuk mengadakan penelitian dan perencanaan untuk kepentingan pengelolaan taman nasional. ${ }^{39}$

Terletak di dua kabupaten (Malinau dan Nunukan). Proses demokratisasi dan isu desentralisasi di Indonesia di akhir tahun 1990an menuntut beberapa perubahan paradigma pembangunan, termasuk bidang pengelolaan sumberdaya alam. Dalam hal ini, TNKM dalam pengelolaannya tidak terlepas dari keterlibatan pemerintah daerah setempat yaitu Malinau (1.012.734 ha) dan Nunukan (347.766 ha) Belum ada unit pelaksana teknis. Walau telah ditunjuk pada tahun 1996, TNKM belum memiliki Unit Pelaksana Teknis yang disebabkan keterbatasan dana dan sumber daya manusia di Departemen Kehutanan. Hal ini akan cukup membuka peluang terjadinya ketidakjelasan status TNKM di daerah. Pada tahun 2004 dikeluarkan SK Menteri Kehutanan tentang penunjukkan pengelola TNKM kepada balai KSDA Kalimantan Timur. ${ }^{40}$

\section{Proses Membangun Kolaborasi ${ }^{41}$}

Proses membangun satu pengelolaan kawasan yang melibatkan masyarakat diawali dan difasilitasi oleh WWF Indonesia dan masyarakat adat antara lain melalui:

1. Pertemuan-pertemuan antara masyarakat adat dengan Direktorat Jenderal Perlindungan Hutan dan Konservasi Alam (Ditjen PHKA) Departemen Kehutanan;

2. Satu forum (Forum Musyawarah Masyarakat Adat) yang dibentuk oleh masyarakat adat yang ada di dalam dan sekitar kawasan TNKM atas kesepakatan para Ketua Adat dan Kepala Adat Besar 11 wilayah adat pada tanggal 7 Oktober 2000;

3. Proses Pemetataan Desa Partisipatif (PDP) untuk mengetahui tata ruang kelola hutan oleh masyarakat di 11 wilayah adat;

\footnotetext{
${ }^{39}$ Dirjen Perlindungan Hutan Dan Konservasi Alam, "Rencana Pengelolaan Taman Nasional Kayan Mentarang," in 1, 1st ed. (Jakarta: Kementerian Kehutanan Indonesia, n.d.), 1.

${ }^{40}$ Dirjen Perlindungan Hutan Dan Konservasi Alam, "Rencana Pengelolaan Taman Nasional Kayan Mentarang 2001-2025 Buku II : Data, Proyeksi Dan Analisis. Departemen Kehutanan Direktorat Jenderal Perlindungan Hutan Dan Konservasi Alam," in 2 (Tarakan: Direktorat Jenderal Perlindungan Hutan dan Konservasi Alam, 2002), 3.

${ }^{41}$ Briefing Paper No. 2: Menuju Manajemen Kolaborasi di Taman Nasional Kayan Mentarang, Forests and Climate Change.
} 
4. Konsultasi publik tentang hasil PDP, usulan batas luar dan peraturan pemanfaatan sumberdaya alam;

5. Rencana Pengelolaan Taman Nasional Kayan Mentarang (RPTNKM) yang mengarahkan bahwa pengelolaan taman nasional berbasis masyarakat dengan membentuk kelembagaan kolaboratif (Dewan Penentu Kebijakan) dan Badan Pengelola.

Pengelolaan kolaboratif di TNKM didasarkan pada (i) TN tidak dapat dilindungi dan dikelola tanpa dukungan aktif masyarakat adat, (ii) Memastikan bahwa manfaat kawasan taman nasional dapat dimanfaatkan secara lestari yang merupakan sumber identitas budaya dan penghidupan masyarakat, (iii) Mengembangkan alternatif ekonomi berbasis konservasi untuk masyarakat dan pemerintah setempat.

Beberapa keputusan yang dibuat Menteri Kehutanan berkaitan dengan Pengelolaan koloratif adalah : SK Menhut No 1213/Kpts-II/2002 tentang Rencana Pengelolaan Taman Nasional (RPTN), No. 1214/Kpts-II/2002 tentang Pengelolaan Kolaboratif TNKM dan No. 1215/Kpts-II/2002 tentang Pembentukan Dewan Penentu Kebijakan (DPK). Peraturan Menteri Kehutanan No. P.19/Menhut-II/2006 tentang Pengelolaan Kolaborasi di Kawasan Konservasi, SK Menteri Kehutanan No. 374/Menhut-II/2007 tentang Dewan Pembina dan Pengendali Pengelolaan Kolaboratif (DP3K). SK Ketua DP3K-TNKM No. 01/DP3K-1/06/2008 pembentukan Sekretariat DP3K TNKM.

Berbagai kegiatan kolaborasi telah dilakukan, antara lain pembentukan Pam Swakarsa, proses penataan batas dan zonasi partisipatif. Seperti Proses penataan batas (TNKM) telah dilakukan secara konsultatif. Semua stakeholder utama terlibat maksimal dalam proses tata batas TNKM. Proses konsultatif tata batas yang didukung oleh WWF Indonesia sejak tahun 2006 didukung oleh Kerjasama Indonesia - Jerman Program Pengembangan Taman Nasional Kayan Mentarang (GTZ). Hasil dari konsultatif tata batas ini dituangkan dalam proposal batas luar TNKM. Demikian juga Zonasi, Hasil Pemetaan Desa Partisipatif (PDP) klasifikasi lahan versi masyarakat adalah peruntukan lahan yang akan menjadi landasan bagi penyusunan zonasi TNKM. Klasifikasi lahan tsb. adalah (a) areal pemukiman, (b) lahan pertanian, (c) padang rumput dan penggembalaan ternak, (d) kawasan hutan (pemanfaatan terbatas, sehari-hari, dan tanah ulen), (e) situs bersejarah/budaya. Berdasarkan konsep dan praktek pemanfaatan SDA oleh masyarakat adat maka masyarakat adat merekomendasikan 3 jenis zonasi, yaitu zona inti, zona pemanfaatan tradisional dan zona khusus agar lebih mudah dipahami dan dipatuhi oleh masyarakat sendiri. Berdasarkan Peraturan Menteri Kehutanan Nomor P.56/Menhut-II/2006 tentang Pedoman Zonasi Taman Nasional, maka zona dalam taman nasional minimal terdiri dari zona inti, zona rimba, dan zona pemanfaatan, kemudian ada zona-zona lain (zona tradisional, zona rehabilitasi, zona religi-sejarah-budaya, dan zona khusus). Dalam 
Permenhut ini juga dikatakan bahwa sekurang-kurangnya taman nasional harus memiliki zona inti, zona rimba, dan zona pemanfaatan. Penataan zonasi taman nasional didasarkan pada potensi dan fungsi kawasan dengan memperhatikan aspek ekologi, sosial, ekonomi, dan budaya. 42

Salah satu keberhasilan dari pengelolaan kolaboratif yaitu telah disepakati zonasi dari TNKM yang terdiri dari zona inti, zona rimba, zona pemanfaatan, zona tradisonal, dan zona khusus yang berdasarkan rumusan kriteria dan indikator zonasi oleh semua lembaga kolaborasi (BTNKM, DP3K, dan FoMMA) TNKM dengan memadukan kepentingan masyarakat (adat) dan kepentingan pemerintahan (PerMenhut).43

Bagi perlindungan TNKM, sebagai Buffer Zone ditinggalkan kepada masyarakat hukum adat wilayah hak ulayatnya. Pengertian Buffer Zone.44 Secara konseptual, "buffer zone" atau wilayah penyangga berfungsi untuk menyangga wilayah utama, mencegah terjadinya kerusakan dan memberikan lapisan perlindungan tambahan. Biasanya penyangga fisik/ekologi terletak di luar kawasan taman nasional. Menurut Undang-Undang Nomor 5 Tahun 1990 tentang Konservasi Sumberdaya Alam Hayati dan Ekosistemnya, dinyatakan bahwa daerah penyangga merupakan wilayah yang berada di luar kawasan suaka alam maupun kawasan pelestarian alam, baik sebagai kawasan hutan lain, tanah negara maupun tanah yang dibebani hak, yang diperlukan dan mampu menjaga keutuhan suaka alam dan kawasan pelestarian alam.

Kebijakan kolaboratif merupakan solusi yang diambil pemerintah atas kepentingan taman nasional dan masyarakat hukum adat yang mendiami kawasan tersebut. Taman nasional merupakan kepentingan yang lebih luas, namun masyarakat hukum adat juga merupakan tangung jawab negara yaitu meningkatkan kesejahteraan rakyat. Masyarakat yang mendiami kawasan tersebut telah membuktikan kearifan lokalnya terhadap hutan lingkungannya, mengapa tidak dipercaya turut mengelola taman nasional. Kolaboratif merupakan kebijakan pemerintah mengatasi permasalahan taman nasional yang masih diduduki oleh masyarakat. Masyarakat menduduki kawasan hutan akan diperhadapkan dengan aturan dikenakan sanksi pidana sebagai perambah hutan. Fakta menunjukan bahwa masyarakat telah mendiami wilayah tersebut sejak nenek moyangnya dan menganggap sebagai wilayahnya karena itu memberi nama sungai, lembah, dataran dan gunung menurut bahasa daerahnya. Difasilitasi WWF disepakati pemerintah dan masyarakat yang mendiami dan di sekitar kawasan hutan taman nasional dengan pola pengelolaan kolaboratif.

\section{Ibid. \\ ${ }^{43}$ Ibid.}

${ }^{44}$ Briefing Paper No. 6: Deliniasi Buffer Zone Dan Pengembangannya Di Sekitar Taman Nasional Kayan Mentarang Dengan Menggunakan Sistem Informasi Geografis (SIG) 
Melibatkan masyarakat hukum adat dalam pengelolaan taman nasional merupakan penghargaan dan mendudukan sebagai subjek hukum yang sederajat. Bermakna tugas dan tanggung jawab atas kesepakataan bersama untuk mengelola: tata hutan dan penyusunan rencana pengelolaan hutan, pemanfaatan hutan dan penggunaan kawasan hutan, rehabilitasi dan reklamasi hutan, perlindungan hutan dan konservasi alam.

Berdasarkan Undang-Undang Nomor 41 Tahun 1999 tentang Kehutanan, sebagai kawasan hutan pengelolaan Taman Nasional juga perlu memperhatikan asas-asas penyelenggaraan kehutanan yaitu manfaat dan lestari, kerakyatan, keadilan, kebersamaan, keterbukaan, dan keterpaduan. Maksudnya bahwa penyelenggaraan kehutanan diharuskan:

a. memperhatikan keseimbangan dan kelestarian unsur lingkungan, sosial dan budaya, serta ekonomi;

b. memberikan peluang dan kesempatan yang sama kepada semua warga negara sesuai dengan kemampuannya, sehingga dapat meningkatkan kemakmuran seluruh rakyat. Oleh karena itu, dalam pemberian wewenang pengelolaan atau izin pemanfaatan hutan harus dicegah terjadinya praktek monopoli, monopsoni, oligopoli, dan oligopsoni;

c. menerapkan pola usaha bersama sehingga terjalin saling keterkaitan dan saling ketergantungan secara sinergis antara masyarakat setempat dengan BUMN atau BUMD, dan BUMS Indonesia, dalam rangka pemberdayaan usaha kecil, menengah, dan koperasi;

d. agar setiap kegiatan penyelenggaraan kehutanan mengikutsertakan masyarakat dan memperhatikan aspirasi masyarakat;

e. agar setiap penyelenggaraan kehutanan dilakukan secara terpadu dengan memperhatikan kepentingan nasional, sektor lain, dan masyarakat setempat.

Pada penjelasan Pasal 30 Undang-Undang Nomor 41 Tahun 1999, disebutkan bahwa dalam kerjasama dengan kearifan tradisional dan nilai-nilai keutamaan, yang terkandung dalam budaya masyarakat dan sudah mengakar, dapat dijadikan aturan yang disepakati bersama. Dari uraian tersebut dapat disimpulkan bahwa pengelolaan taman nasional wajib melibatkan masyarakat.

Agar dapat melibatkan masyarakat hukum adat Dayak dalam pengelolaan TNKM, maka perlu adanya pengelolaan kolaboratif. Pengelolaan kolaboratif diartikan sebagai kesepakatan dua atau lebih pemangku kepentingan untuk membagi informasi, peran, fungsi dan tanggung jawab dalam suatu hubungan dan mekanisme kemitraan (partnership) yang disetujui secara bersama. 45

\footnotetext{
${ }^{45}$ Borrini-Feyerabend, G., Farvar, M.T., Nguinguiri, J.C., Ndangang, V. 2000. Co-management of natural resources: Organizing negotiation and learning by doing Kasparek, Heidelberg (germany). http://nrm.massey.ac.nz/ changelink/cmnr.html
} 
Ciri khas kolaborasi adalah proses saling belajar (sharing), terutama berbagi informasi. Dalam proses mencapai tujuan seringkali dilakukan penyesuaian terus menerus atau adaptif. 46

Dalam proses pembentukan kolaborasi sangat penting diciptakan mekanisme partisipasi. Partisipasi dapat berjalan ketika seluruh pemangku kepentingan memiliki hak untuk mengakses dan mendapatkan informasi, rencana penyusunan kebijakan publik, dan rencana-rencana kegiatan pembangunan lainnya, menyatakan pendapat serta menyampaikan usulan-usulan agar kegiatan proyek, kebijakan publik dan rencana pembangunan dapat memberikan manfaat dan keuntungan untuk seluruh pemangku kepentingan.

Pentingnya partisipasi adalah sebagai berikut: pertama, partisipasi masyarakat merupakan suatu alat guna memperoleh informasi mengenai kondisi, kebutuhan, dan sikap masyarakat setempat, yang tanpa kehadirannya program pembangunan serta proyek-proyek akan gagal; kedua, bahwa masyarakat akan lebih mempercayai proyek atau program pembangunan jika merasa dilibatkan dalam proses persiapan dan perencanaannya, karena mereka akan lebih mengetahui seluk-beluk proyek tersebut dan akan mempunyai rasa memiliki terhadap proyek tersebut; ketiga, bahwa merupakan suatu hak demokrasi bila masyarakat dilibatkan dalam pembangunan masyarakat mereka sendiri. Oleh karena itu, masyarakat harus dilibatkan dalam pembuatan kebijakan dengan memanfaatkan ruang publik yang ditawarkan oleh Habermas dalam bentuk partisipasi politik. Dengan partisipasi politik maka masyarakat dapat mempengaruhi pemerintah dan meminta komitmen serta akuntabilitas pemerintah. ${ }^{47}$

Pengelolaan kolaboratif TNKM antara pemerintah dan masyarakat adat Dayak meniscayakan adanya upaya mengadopsi atau mengangkat kearifan lokal dan hukum adat dalam pengaturan atau peraturan perundang-undangan tentang taman nasional khususnya pada TNKM.

\section{CONCLUSION AND POLICY RECOMENDATION}

3.1. Pengakuan Masyarakat Hukum adat dan hak tradisionalnya diatur secara tegas dalam UUD NKRI 1945, selanjutnya dijabarkan dalam peraturan perundangan-undangan, selanjutnya secara bertahap diwujudkan.

3.2. Masyarakat hukum adat dengan kearifan lokalnya diikutsertakan dalam pengelolaan Taman Nasional Kayan Mentarang secara kolaboratif untuk mengakomodasi

\footnotetext{
${ }^{46}$ Carlsson, Lars. Berkes, Fikret. 2005. Comanagement: concepts and methodological implications. Jour Env. Man 75: 65-76

${ }^{47}$ Cornwall, Andrea, Gaventa, John, 2001. Form Users and Chooser to Makers and Shapers: Repositioning Participation in Social Policy, IDS Working Paper 127, Juni 2001, hlm. 127.
} 
ketergantungan kepada hutan guna meningkatkan taraf hidup masyarakat hukum adat sekaligus diberi kehormatan menjaga TNKM.

\section{BIBLIOGRAPHY}

A. Suriyaman Mustari Pide. Dilema Hak Kolektif Eksistensi Dan Realitas Sosialnya Pasca UUPA. makassar: Pelita Pustaka, 2007.

Alam, Dirjen Perlindungan Hutan Dan Konservasi. "Rencana Pengelolaan Taman Nasional Kayan Mentarang." In 1, 1st ed., 1. Jakarta: Kementerian Kehutanan Indonesia, n.d.

___. "Rencana Pengelolaan Taman Nasional Kayan Mentarang 2001-2025 Buku II : Data, Proyeksi Dan Analisis. Departemen Kehutanan Direktorat Jenderal Perlindungan Hutan Dan Konservasi Alam." In 2, 3. Tarakan: Direktorat Jenderal Perlindungan Hutan dan Konservasi Alam, 2002.

Alting, Husen. Dinamika Hukum Dalam Pengakuan Dan Perlindungan Hak Masyarakat Hukum Adat Atas Tanah, (Musa Lalu, Kini Dan Masa Mendatang),. Yogyakarta: Penerbit LaksBang PRESSindo, 2011.

Bakri, Muhammad. Hak Menguasai Tanah Oleh Negara (Paradigma Baru Untuk Reformasi Agraria). Yogyakarta, 2007.

Besar, kepala-kepala adat. “Pertanian Organik.” Long Bawan, 2017.

Ernawi, Imam S. “Harmonisasi Kearifan Lokal Dalam Regulasi Penataan Ruang.” IBDA 5, no. 1 (2007): 27-38.

Griya. "Kearifan Lokal Dalam Perspektif Kajian Budaya Pergulatan Teoritik Dan Ranah Aplikatif (Program Magister Kajian Budaya." Udayana, 2004.

Hadjon, Philipus. Pengatar Hukum Administrasi Indonesia (Introduction to the Indonesian Administrative Law). Yogyakarta: Gadjah Mada University Press, 1993.

Hadjon Philipus, and Djatmiati Tatiek. Hadjon Philipus. Gaja Mada University, 2005.

Mahmud, Peter. Penelitian Hukum. Jakarta: Kencana Prenada Media Group, 2009.

Marthin. “Prinsip Hukum Pengelolaan Hutan Pada Tanah Ulayat.” Airlangga, 2015.

Marthin, Yahya Zein, and Arif Rohman. "Problematika Penetapan Kawasan Hutan Di Wilayah Masyarakat Adat Dalam Rangka Pembangunan Berkelanjutan Di Kota Tarakan." Jurnal Pandecta 9, no. 1 (2014).

Rato Dominikus. Pengantar Hukum Adat. Yogyakarta: Laksbang Pressindo, 2009.

S, Salim, and Septiana Erlies Nurbani. Penerapan Teori Hukum Pada Penelitian Tesis Dan Disertasi, 2013.

Soepomo. Bab-Bab Tentang Hukum Adat. Jakarta: Pradya Paramita, 2000.

Swarsi, S. ", Fungsi Kearifan Lokal Dalam Pembangunan Kualitas Sumber Daya Manusia 
(Laporan Penelitian, Balai Kajian Sejarah Dan Nilai Tradisional Denpasar." Denpasar, 2004.

Uluk Asung, Dkk. "Ketergantungan Masyarakat Dayak Terhadap Hutan Di Sekitar Taman

Nasional Kayan Mentarang." Taman Nasional Kayan Mentarang, 2001.

Wikipedia. “Taman Nasional Kayan Mentarang.” id.wikipedia.org, 2018. 